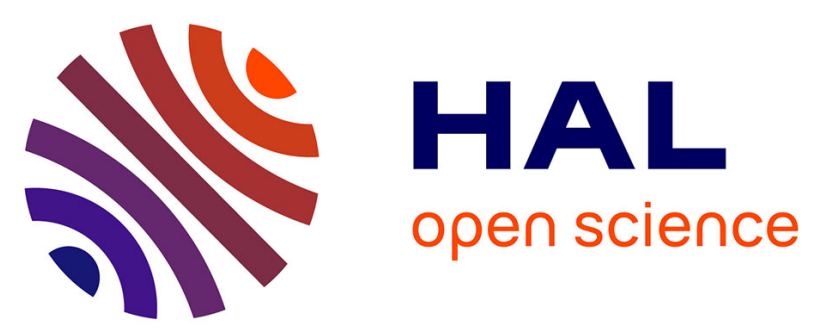

\title{
Domino Methylenation/Hydrogenation of Aldehydes and Ketones by Combining Matsubara's Reagent and Wilkinson's Catalyst
}

Radhouan Maazaoui, María Pin-Nó, Kevin Gervais, Raoudha Abderrahim, Franck Ferreira, Alejandro Perez-Luna, Fabrice Chemla, Olivier Jackowski

\section{To cite this version:}

Radhouan Maazaoui, María Pin-Nó, Kevin Gervais, Raoudha Abderrahim, Franck Ferreira, et al.. Domino Methylenation/Hydrogenation of Aldehydes and Ketones by Combining Matsubara's Reagent and Wilkinson's Catalyst. European Journal of Organic Chemistry, 2016, 2016 (34), pp.5732-5737 10.1002/ejoc.201601137 . hal-01396579

\section{HAL Id: hal-01396579 \\ https://hal.sorbonne-universite.fr/hal-01396579}

Submitted on 14 Nov 2016

HAL is a multi-disciplinary open access archive for the deposit and dissemination of scientific research documents, whether they are published or not. The documents may come from teaching and research institutions in France or abroad, or from public or private research centers.
L'archive ouverte pluridisciplinaire HAL, est destinée au dépôt et à la diffusion de documents scientifiques de niveau recherche, publiés ou non, émanant des établissements d'enseignement et de recherche français ou étrangers, des laboratoires publics ou privés. 


\title{
Domino Methylenation-Hydrogenation of Aldehydes and Ketones by Combining Matsubara's Reagent and Wilkinson's Catalyst
}

\author{
Radhouan Maazaoui, ${ }^{[a][b]}$ María Pin-Nó, ${ }^{[a]}$ Kevin Gervais, ${ }^{[a]}$ Raoudha Abderrahim, ${ }^{[b]}$ Franck Ferreira,${ }^{[a]}$ \\ Alejandro Perez-Luna, ${ }^{[a]}$ Fabrice Chemla ${ }^{\star[a]}$, Olivier Jackowski ${ }^{*[a]}$
}

\begin{abstract}
The methylenation-hydrogenation cascade reaction of aldehydes or ketones through a domino process involving two ensuing steps in a single pot is related. The compatibility of Matsubara's reagent and Wilkinson's complex afford a combination that allows, under dihydrogen atmosphere, the transformation of carbonyl function into a methyl group. This new method is suitable to introduce an ethyl motif from aromatic and aliphatic aldehydes, with total chemoselectivity and total retention of $\alpha$-stereochemical purity. The developed procedure is also extended to the introduction of methyl group from ketones.
\end{abstract}

\section{Introduction}

Development of new synthetic processes that meet both economic and environmental needs is one of the major challenges in organic chemistry and its main source of innovation. Finding new strategies that reduce the number of elementary operations required to achieve a given transformation participates to this effort since it allows significant waste diminution. ${ }^{[1]}$ Thus, in this context, one-pot multiple transformations have attracted an ever-increasing interest. ${ }^{[2,3]}$ Carbonyl methylenation is an important method for $\mathrm{C}-\mathrm{C}$ bond formation because the resulting alkene offers a valuable handle for further elaboration. However, processes wherein the generated alkene undergoes a subsequent transformation in the same reaction media are scarce. ${ }^{[4]} \mathrm{A}$ case to the point is the combination of aldehyde methylenation and hydrogenation. This sequence is a common strategy to introduce an ethyl group from aldehydes in multi-step synthesis of natural products, ${ }^{[5]}$ bioactive analogues ${ }^{[6]}$ or key intermediates. ${ }^{[7]}$ Typically, the transformation is performed through a two-step/two-batch procedure involving a Wittig-type reaction followed by a Pd- or Pt-catalyzed hydrogenation (Scheme 1, top). But use of large volume of solvent and elimination of phosphine oxide by-product are major restrictions of this method. Another drawback is the basic conditions met in the Wittig reaction that could lead to the loss of $\alpha$-stereochemical purity by enolization of aldehydes. Finally, the lack of chemoselectivity of phosphorus ylide reagents between aldehydes and ketones is another common limitation, and diene

[a] R. Maazaoui, M. Pin-Nó, K. Gervais, F. Ferreira, A. Perez-Luna, F. Chemla, O. Jackowsk

Institut Parisien de Chimie Moléculaire (IPCM),

Sorbonne Universités, UPMC Univ Paris 06, CNRS UMR 8232

CC 229, 4 place Jussieu, F-75252 Paris Cedex 05, France

E-mail: olivier.jackowski@upmc.fr; fabrice.chemla@upmc.fr www.ipcm.fr

[b] R. Maazaoui, R. Abderrahim

Laboratoire de Synthèse Hétérocyclique, Université de Carthage,

Faculté des Sciences de Bizerte, 7021 Jarzouna. Bizerte, Tunisia formation from compounds presenting both aldehyde and ketone moieties is generally observed. For all these drawbacks, the availability of a more direct and selective method avoiding intermediate purifications is required. Such a method could be attained through a all-in-one-pot domino sequence involving two subsequent steps.

To the best of our knowledge, only a single one-pot alternative to Wittig methylenation-hydrogenation has been disclosed to date ${ }^{[8]}$ it combines methylenation and hydrogenation both catalyzed by rhodium complexes. However, the two processes cannot be performed simultaneously and the methylenation needs to be completed prior initiation of the hydrogenation (Scheme 1, middle).

In order to develop a true domino methylenation-hydrogenation alternative method, we therefore examined the use of methylenedizinc reagents: $:^{[9]}$ these are known to be less basic than Wittig reagents and we expected in this case the reaction side products (zinc salts) generated through the methylenation step would to be inert towards the hydrogenation catalyst. Reagent such as Nysted's reagent 1 and Matsubara's reagent 2 $\left[\mathrm{CH}_{2}(\mathrm{Znl})_{2}\right]$ present also the advantage of being chemoselective between aldehydes and ketones and to react with $\alpha$-chiral aldehydes without loss of the stereochemical integrity. For the double bond reduction, we considered the commercially available and widely used Wilkinson's catalyst $\left(\mathrm{CIRh}\left(\mathrm{PPh}_{3}\right)_{3}\right)^{[10]}$ (Scheme 1, bottom).

Two-step / two-batch sequence (Wittig chemistry) :

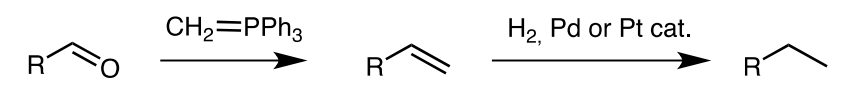

One-pot sequential approach $: 8$

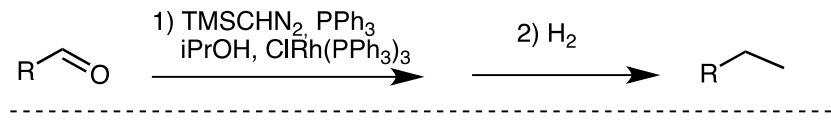

One-pot domino approach (this work) :

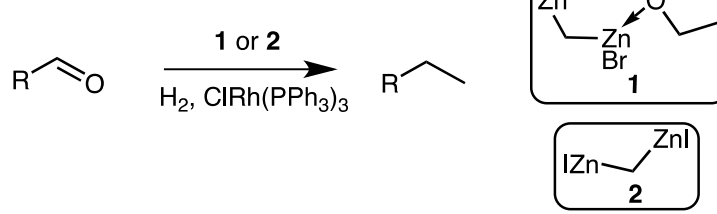

Scheme 1. Methylenation-hydrogenation sequences. 
Naturally the viability of such an approach is directly related to the compatibility of the methylenation reagent with the hydrogenation catalyst, and this had to be verified first.

\section{Results and Discussion}

To explore this one-pot domino approach, we focused first on the commercially available Nysted's reagent $\mathbf{1}^{[11]}$ (Table 1). The transformation of the aldehyde moiety into an ethyl group was first attempted by a sequential addition. At $0{ }^{\circ} \mathrm{C}$, reagent 1 was added to aldehyde 3 in the presence of $\mathrm{BF}_{3} \cdot \mathrm{OEt}_{2}$ ( 1 equiv) and the mixture was warmed to $25^{\circ} \mathrm{C}$. The complete consumption of 3 was observed within $2 \mathrm{~h}$. The reaction flask was then flushed with $\mathrm{H}_{2}(1 \mathrm{~atm})$ and Wilkinson's catalyst $(10 \mathrm{~mol} \%)$ was introduced. Alkane 4 was isolated in $58 \%$ yield after $48 \mathrm{~h}$ (entry 1). In a second experiment, at $0{ }^{\circ} \mathrm{C}$ all reagents (aldehyde 3 , $\mathrm{BF}_{3} \cdot \mathrm{Et}_{3} \mathrm{O}$ and Wilkinson's catalyst) were introduced in the flask, previously flushed with $\mathrm{H}_{2}(1 \mathrm{~atm})$, and the resulting mixture gradually allowed to warm to $25^{\circ} \mathrm{C}$. Alkane 4 was isolated in a lower $27 \%$ yield (entry 2 ). Pleasingly, adding all reagents at $78{ }^{\circ} \mathrm{C}$ prior to warming the mixture to $25^{\circ} \mathrm{C}$ led to the formation of alkane 4 in a $62 \%$ yield (entry 3 ), showing the viability of our one-pot domino approach. However confronted to a lack of reproducibility of these results (attributed to the heterogeneity of Nysted's reagent 1), we decided to turn to THF-soluble Matsubara reagent $2^{[12]}$ known to be a methylenating reagent of aldehydes that does not require Lewis acid activation. ${ }^{[13]}$

Table 1. Optimization studies.
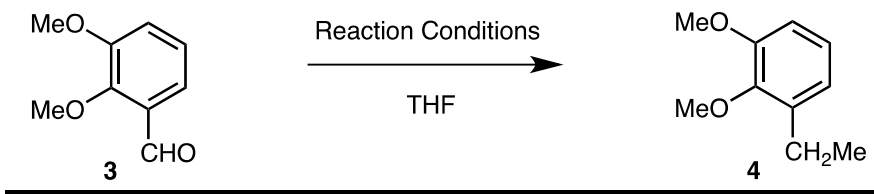

\begin{tabular}{|c|c|c|}
\hline Entry & Reaction Conditions & Yield $(\%)^{[\mathrm{a}]}$ \\
\hline 1 & $\begin{array}{l}1 \text { (1 equiv), } \mathrm{BF}_{3} \cdot \mathrm{Et}_{2} \mathrm{O}\left(1 \text { equiv), } 0{ }^{\circ} \mathrm{C} \text { then } 2 \mathrm{~h} \text { at } 25^{\circ} \mathrm{C} \text {, }\right. \\
\text { then } \mathrm{H}_{2}(1 \mathrm{~atm}), \mathrm{CIRh}\left(\mathrm{PPh}_{3}\right)_{3}(10 \mathrm{~mol} \%), 48 \mathrm{~h}\end{array}$ & 58 \\
\hline 2 & $\begin{array}{l}1 \text { (1 equiv), } \mathrm{BF}_{3} \cdot \mathrm{Et}_{2} \mathrm{O}\left(1 \text { equiv), } \mathrm{H}_{2}(1 \mathrm{~atm}), \mathrm{CIRh}\left(\mathrm{PPh}_{3}\right)_{3}\right. \\
(10 \mathrm{~mol} \%), 0^{\circ} \mathrm{C} \text { to } 25^{\circ} \mathrm{C}, 48 \mathrm{~h}\end{array}$ & 27 \\
\hline 3 & $\begin{array}{l}1 \text { (1 equiv), } \mathrm{BF}_{3} \cdot \mathrm{Et}_{2} \mathrm{O} \text { (1 equiv), } \mathrm{H}_{2}(1 \mathrm{~atm}), \mathrm{CIRh}\left(\mathrm{PPh}_{3}\right)_{3} \\
(10 \mathrm{~mol} \%),-78^{\circ} \mathrm{C} \text { to } 25^{\circ} \mathrm{C}, 48 \mathrm{~h}\end{array}$ & $62^{[\mathrm{b}]}$ \\
\hline 4 & $\begin{array}{l}2 \text { (1 equiv), } \mathrm{H}_{2}(1 \mathrm{~atm}), \mathrm{CIRh}\left(\mathrm{PPh}_{3}\right)_{3}(10 \mathrm{~mol} \%),-78{ }^{\circ} \mathrm{C} \\
\text { to } 25^{\circ} \mathrm{C}, 48 \mathrm{~h}\end{array}$ & 67 \\
\hline 5 & $\begin{array}{l}2 \text { (1 equiv), } \mathrm{H}_{2}(1 \mathrm{~atm}), \mathrm{CIRh}\left(\mathrm{PPh}_{3}\right)_{3}(6.5 \mathrm{~mol} \%),-78{ }^{\circ} \mathrm{C} \\
\text { to } 25^{\circ} \mathrm{C}, 48 \mathrm{~h}\end{array}$ & 66 \\
\hline 6 & $\begin{array}{l}2 \text { (1.2 equiv), } \mathrm{H}_{2}(1 \mathrm{~atm}), \mathrm{CIRh}\left(\mathrm{PPh}_{3}\right)_{3}(6.5 \mathrm{~mol} \%) \\
25^{\circ} \mathrm{C}, 48 \mathrm{~h}\end{array}$ & 75 \\
\hline 7 & $\begin{array}{l}2 \text { (1.2 equiv), } \mathrm{H}_{2}(1 \mathrm{~atm}), \mathrm{CIRh}\left(\mathrm{PPh}_{3}\right)_{3}(3 \mathrm{~mol} \%), 25^{\circ} \mathrm{C} \text {, } \\
48 \mathrm{~h}\end{array}$ & $28^{[c]}$ \\
\hline
\end{tabular}

[a] Isolated yield. [b] not reproducible. [c] $50 \%$ of 2,3-dimethoxystyrene was isolated.
To our delight a reproducible $67 \%$ yield (entry 4 ) was obtained under our former one-pot conditions (addition at $-78{ }^{\circ} \mathrm{C}$ then warming to $25^{\circ} \mathrm{C}$ ). Interestingly, the catalyst loading could be diminished to $6.5 \mathrm{~mol} \%$ without erosion of the yield (entry 5). Our best result was obtained by carrying out the whole process at $25{ }^{\circ} \mathrm{C}$. Under these optimized conditions, alkane 4 could be formed in significantly better $75 \%$ isolated yield (entry 6 ). The use of only $3 \mathrm{~mol} \%$ of this catalyst was however shown to be detrimental (entry 7) as partial reduction was observed.

With these optimized conditions in hands, various aldehydes were subjected to our all-in-one-pot domino conditions (Scheme 2 ). In the aromatic series, a range from $65 \%$ to $80 \%$ yield was observed. Steric hindrance did not show any impact as illustrated by comparison of the yields between alkanes 5 and 6 or 4 and 8. The influence of electronic effects on the aromatic group was also investigated: aldehydes presenting either electron-poor aromatic rings (compound 13) or electron-rich ones (products 4, 8 and 9) gave the corresponding products in similar yields $(71-80 \%)$. On the other hand aliphatic aldehydes were converted into the corresponding alkanes in slightly lower yields (55-78\%). Here again no impact of the steric hindrance was observed as $\square$-mono-, di- or tri-substituted aldehydes were transformed into the corresponding alkanes 10-12 in comparable (69-81\%) yields.
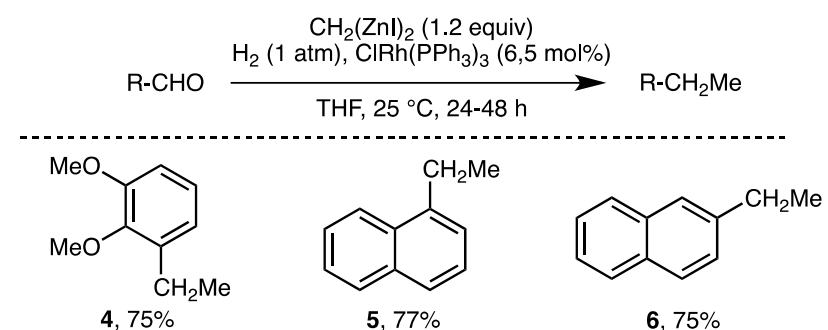<smiles>CCc1ccc(Br)cc1</smiles><smiles>CCc1ccc(OC)c(OC)c1</smiles>

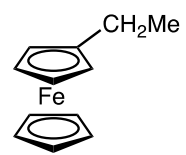

$9,80 \%$
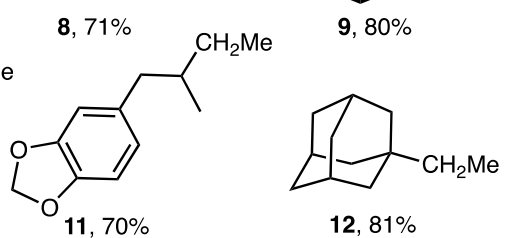

$12,81 \%$

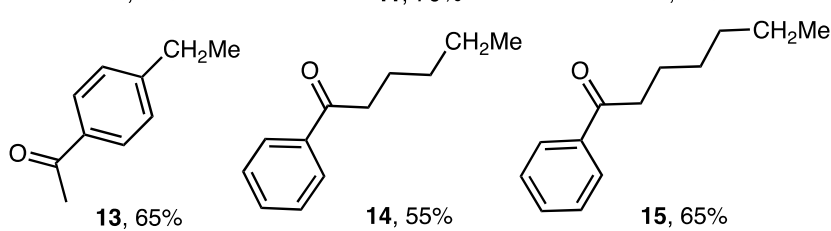

$13,65 \%$

$15,65 \%$<smiles>CCC(C)COC(c1ccccc1)(c1ccccc1)c1ccccc1</smiles>

$16,78 \%$, ee $=99 \%$

Scheme 2. One-pot domino methylenation-hydrogenation from aldehydes. 
Importantly, as the methylenation using $\mathbf{2}$ is known to be chemoselective, ${ }^{[13 a, b]}$ our one-pot domino procedure tolerates the presence of ketone moieties. As illustrated by the formation of products 13-15, substrates bearing both an aldehyde and a ketone moiety undergo methylenation-hydrogenation of the aldehyde by leaving the ketone intact. By comparison, Wittig methylenation of such substrates usually affords not only the desired methylenated products but also diene side products. ${ }^{[14]}$

Finally, we verify that our conditions also allow the transformation of enolizable chiral aldehydes without loss of chiral integrity. While Wittig reaction is likely to induce aldehyde isomerization, no epimerization occurs with $2^{[13 a, 13 b, 15]}$ Thus, (2S)-2-methyl,3-trityloxypropanal (99\% ee) afforded alkane 16 in $78 \%$ yield and identical ee (99\%).

Our conditions thus offer a new easy method to transform aldehydes into ethyl group with a great chemoselectivity and a total retention of the $\alpha$-stereochemical information of the aldehyde. To gain insight into the interplay of the different elements of our system, we carried out several control experiments with 2-naphthaldehyde 17 (Scheme 3). In a first experiment, the methylenation step was monitored by in situ $I R^{[16]}$ analysis in presence of Wilkinson's catalyst under $\mathrm{H}_{2}$ atmosphere. The methylenation step was observed to be fast as 95\% conversion of $\mathbf{1 7}$ was achieved within $20 \mathrm{~min}$ and alkene 18 was isolated in $85 \%$ yield (eq. 1). Another control experiment was conducted by mixing Wilkinson's catalyst and 2 for $2 \mathrm{~h}$ under $\mathrm{H}_{2}$ prior to the addition of alkene 18 (eq. 2). Product 5 was obtained in $80 \%$ yield, thus proving that the mixture of Wilkinson's catalyst and $\mathbf{2}$ is still active for the hydrogenation process. In the last experiment, a mixture of Wilkinson's catalyst and 2 was stirred under $\mathrm{H}_{2}$ for $2 \mathrm{~h}$ and thus aldehyde 17 was added (eq. 3).

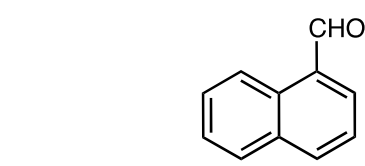

$$
\Gamma_{I Z n}^{Z n \mid}
$$$$
17 \text { ( } 0.85 \text { equiv) }
$$

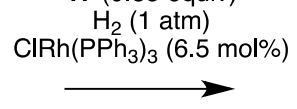

$$
\text { THF }
$$$$
20 \mathrm{~min}, 25^{\circ} \mathrm{C}
$$<smiles>C=Cc1cccc2ccccc12</smiles>

$18,85 \%$<smiles>CCc1cccc2ccccc12</smiles>

$17+$<smiles>OCc1cccc2ccccc12</smiles>

$19,60 \%$

$33 \%$
(1)<smiles>CC1=Cc2ccccc2CC1</smiles><smiles>CC(C)COc1ccccc1</smiles>

$22,82 \%$

$20,86 \%$

$78 \%, 24$ / 25 (73:27)

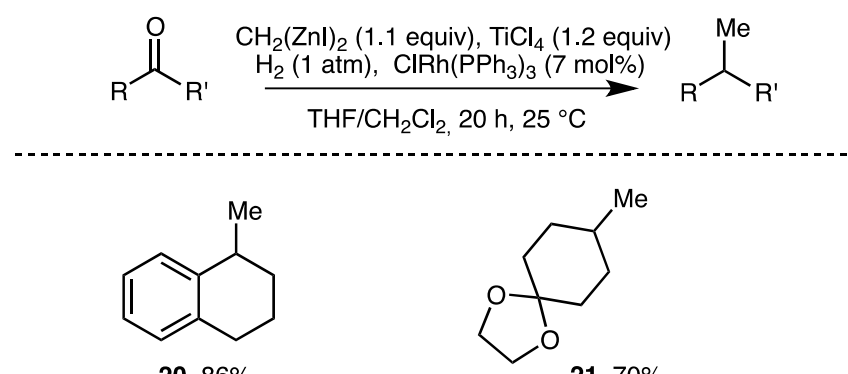
thet and starting material $\mathbf{1 7}$ was recovered in $33 \%$ yield. last result indicates that under these conditions, no methylenation process. These results denote that, even though degradation of organometallic species 2 occurs in the presence of the Wilkinson's catalyst, the kinetics of the methylenation step override reagent decomposition. Thanks to this kinetic difference the one-pot domino approach is possible.

this domino procedure was thus envisioned to or $\mathrm{TiCl}_{4}$ as a Lewis acid is necessary for the methylenation step. ${ }^{[9,13]}$ Hence, our investigation was carried out in a all-in-onepot manner with $\alpha$-Tetralone (1 equiv) in the presence of $\mathrm{TiCl}_{4}$ (1.2 equiv), ${ }^{[17]}$ reagent 2 (1.1 equiv.) and $\mathrm{CIRh}\left(\mathrm{PPh}_{3}\right)_{3}(7 \mathrm{~mol} \%)$ at $25{ }^{\circ} \mathrm{C}$ under $\mathrm{H}_{2}(1 \mathrm{~atm})$. As expected alkane 20 was formed and isolated in $86 \%$ yield (Scheme 4 ). The scope of this domino system was consequently evaluated for a variety of ketones (Scheme 4). Aliphatic ketones were transformed in good yields: alkanes $\mathbf{2 1}$ and $\mathbf{2 2}$ were obtained in respectively $70 \%$ and $82 \%$ yields from the corresponding aliphatic ketones. Ketoesters could also be converted as illustrated by product $\mathbf{2 3}$ isolated in $62 \%$ yield. However, from easily enolizable ketone such as $\beta$ Tetralone known to afford a low yield for the methylenation step, ${ }^{[13 a]}$ a 73:27 mixture of alkane $\mathbf{2 4}$ and alkene 25 was isolated in $\mathbf{7 8} \%$ yield. Alkene $\mathbf{2 5}$ was assumed to result from the double bond migration into the cycle from the exocyclic primarily formed methylenation product. Hydrogenation was also revealed to be sensitive to the steric hindrance of the ketone. Alkane $\mathbf{2 6}$ was indeed obtained in mixture with alkene 27 (26:27 = 80:20) in $85 \%$ yield, even with 12 mol\% of catalyst loading.

$$
\text { 21, } 70 \%
$$<smiles>CC(C)C(=O)OCc1ccccc1</smiles>

23, $62 \%$

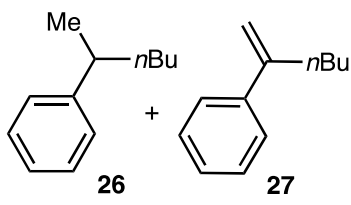

$85 \%, 26 / 27(80: 20)$ 


\section{Conclusions}

In summary, an efficient all-in-one-pot domino process has been developed to perform the transformation of a carbonyl moiety into a methyl group through a methylenation and [Rh]-catalyzed double bond hydrogenation cascade. This new method allows the introduction of an ethyl motif with total chemoselectivity and total preservation of $\alpha$-stereochemical information from various aldehydes. Aromatic and aliphatic aldehydes produced the corresponding alkanes in good yields. Extension of the process to ketones in the presence of $\mathrm{TiCl}_{4}$ represents also a new pathway to introduce the methyl pattern into molecules. This procedure confirms the prospect of domino methylenationalkene transformation cascades by the combination of gemorganodizinc species and Rh catalysts.

\section{Experimental Section}

Representative Procedure A for the Domino MethylenationHydrogenation of aldehydes: Aldehyde $(0.5 \mathrm{mmol})$ was dissolved in dry THF (1 mL) and the flask was flushed with $\mathrm{H}_{2}(1 \mathrm{~atm})$. At $25^{\circ} \mathrm{C}$ under vigorous stirring, were successively added the Wilkinson's catalyst $(6.5$ mol\%) and a $0.50 \mathrm{M}$ soln of 2 in THF $(0,6 \mathrm{mmol}, 1.2 \mathrm{~mL})$. After total consumption of alkene $(24 \mathrm{~h})$, the mixture was directly purified by flash column chromatography over silica gel to give desired compound. All compounds were obtained as oils.

\section{1,2-Dimethoxy-3-ethylbenzene (4) \\ The representative procedure $A$ was followed using 2,3- Dimetoxybenzaldehyde (83 mg, $0.5 \mathrm{mmol})$, Wilkinson's catalyst $(30 \mathrm{mg}$, $6.5 \mathrm{~mol} \%)$ and a $0.50 \mathrm{M}$ soln of $2 \mathrm{in}$ THF $(1.2 \mathrm{~mL}, 0,6 \mathrm{mmol})$. Column chromatography on silica gel (pentane/diethyl ether $100 / 0$ to $90 / 10$ ) yielded 4 (63 mg, 75\%). ${ }^{1} \mathrm{H}$ NMR $\left(400 \mathrm{MHz}, \mathrm{CDCl}_{3}\right): \delta \square(\mathrm{ppm})=1.99-$ $1.89(\mathrm{~m}, 3 \mathrm{H}), 1.75-1.59(\mathrm{~m}, 6 \mathrm{H}), 1.45(\mathrm{~d}, J=2.9 \mathrm{~Hz}, 6 \mathrm{H}), 1.10(\mathrm{q}, J=$ $7.6 \mathrm{~Hz}, 2 \mathrm{H}), 0.79(\mathrm{t}, J=7.6 \mathrm{~Hz}, 3 \mathrm{H}) .{ }^{13} \mathrm{C} \mathrm{NMR}\left(101 \mathrm{MHz}, \mathrm{CDCl}_{3}\right): \delta$ $(\mathrm{ppm})=42.2,37.5,36.9,32.4,29.0,7.0$.}

\section{1-Ethylnaphthalene (5)}

The representative procedure A was followed using 1-Naphthaldehyde (78 mg, $0.5 \mathrm{mmol}$ ), Wilkinson's catalyst ( $30 \mathrm{mg}, 6.5 \mathrm{~mol} \%$ ) and a $0.50 \mathrm{M}$ soln of 2 in THF (1.2 mL, 0,6 mmol). Column chromatography on silica gel (pentane) yielded 5 (61 mg, 77\%). ${ }^{1} \mathrm{H}$ NMR $\left(400 \mathrm{MHz}, \mathrm{CDCl}_{3}\right)$ : $\delta \square(\mathrm{ppm})=8.16-8.10(\mathrm{~m}, 1 \mathrm{H}), 7.92(\mathrm{~d}, J=7.6$ and $2.0 \mathrm{~Hz}, 1 \mathrm{H}), 7.77(\mathrm{~d}$, $J=8.0 \mathrm{~Hz}, 1 \mathrm{H}), 7.63-7.43(\mathrm{~m}, 3 \mathrm{H}), 7.43-7.37(\mathrm{~m}, 1 \mathrm{H}), 3.18(\mathrm{q}, J=7.5$ $\mathrm{Hz}, 2 \mathrm{H}), 1.46$ (t, $J=7.5 \mathrm{~Hz}, 3 \mathrm{H}) .{ }^{13} \mathrm{C} \mathrm{NMR}\left(101 \mathrm{MHz}, \mathrm{CDCl}_{3}\right): \delta(\mathrm{ppm})=$ $140.4,134.0,131.9,128.9,126.5,125.8,125.5,125.0,123.9,26.0,15.2$.

\section{2-EthyInaphthalene (6)}

The representative procedure A was followed using 2-Naphthaldehyde (92 $\mathrm{mg}, 0.5 \mathrm{mmol})$, Wilkinson's catalyst ( $30 \mathrm{mg}, 6.5 \mathrm{~mol} \%$ ) and a $0.50 \mathrm{M}$ soln of 2 in THF (1.2 mL, 0,6 mmol). Column chromatography on silica gel (pentane) yielded 6 (59 mg, 75\%). ${ }^{1} \mathrm{H}$ NMR $\left(400 \mathrm{MHz}, \mathrm{CDCl}_{3}\right)$ : $\delta(\mathrm{ppm})=7.86-7.79(\mathrm{~m}, 3 \mathrm{H}), 7.69-7.64(\mathrm{~m}, 1 \mathrm{H}), 7.51-7.41(\mathrm{~m}, 2 \mathrm{H}), 7.39$ (dd, $J=8.4,1.8 \mathrm{~Hz}, 1 \mathrm{H}), 2.86(\mathrm{qd}, J=7.5,0.8 \mathrm{~Hz}, 2 \mathrm{H}), 1.37(\mathrm{t}, J=7.6$ $\mathrm{Hz}, 3 \mathrm{H}) \cdot{ }^{13} \mathrm{C}$ NMR $\left(101 \mathrm{MHz}, \mathrm{CDCl}_{3}\right): \delta(\mathrm{ppm})=141.9,133.9,132.1$, $127.9,127.7,127.6,127.2,126.0,125.7,125.1,29.2,15.7$.

\section{4-Ethylbromobenzene (7)}

The representative procedure A was followed using 4Bromobenzaldehyde (78 mg, $0.5 \mathrm{mmol}$ ), Wilkinson's catalyst ( $30 \mathrm{mg}, 6.5$ mol\%) and a $0.50 \mathrm{M}$ soln of 2 in THF (1.2 mL, 0,6 mmol). Column chromatography on silica gel (pentane) yielded 7 (71 mg, 76\%). ${ }^{1} \mathrm{H}$ NMR $\left(400 \mathrm{MHz} \mathrm{CDCl}_{3}\right): \delta \square(\mathrm{ppm})=7.42(\mathrm{~d}, J=8.4 \mathrm{~Hz}, 2 \mathrm{H}), 7.09(\mathrm{~d}, J=8.6$ $\mathrm{Hz}, 2 \mathrm{H}), 2.63(\mathrm{q}, J=7.6 \mathrm{~Hz}, 2 \mathrm{H}), 1.25(\mathrm{t}, J=7.6 \mathrm{~Hz}, 3 \mathrm{H}) .{ }^{13} \mathrm{C}$ NMR $\left(101 \mathrm{MHz}, \mathrm{CDCl}_{3}\right): \delta \square(\mathrm{ppm})=143.2,131.4,129.7,119.4,28.4,15.6$.

\section{1,2-Dimethoxy-4-ethylbenzene (8)}

The representative procedure A was followed using 3,4Dimetoxybenzaldehyde (83 mg, $0.5 \mathrm{mmol}$ ), Wilkinson's catalyst (30 mg, $6.5 \mathrm{~mol} \%)$ and a $0.50 \mathrm{M}$ soln of $2 \mathrm{in} \mathrm{THF} \mathrm{(1.2} \mathrm{mL,} \mathrm{0,6} \mathrm{mmol).} \mathrm{Column}$ chromatography on silica gel (pentane/diethyl ether $100 / 0$ to $90 / 10$ ) yielded 8 (60 mg, 71\%). ${ }^{1} \mathrm{H}$ NMR $\left(400 \mathrm{MHz}, \mathrm{CDCl}_{3}\right): \delta \square(\mathrm{ppm})=6.80(\mathrm{~d}, J$ $=8.6 \mathrm{~Hz}, 1 \mathrm{H}), 6.76-6.72(\mathrm{~m}, 2 \mathrm{H}), 3.88(\mathrm{~s}, 3 \mathrm{H}), 3.85(\mathrm{~s}, 3 \mathrm{H}), 2.61(\mathrm{q}, J$ $=7.6 \mathrm{~Hz}, 2 \mathrm{H}), 1.24(\mathrm{t}, J=7.6 \mathrm{~Hz}, 3 \mathrm{H}) .{ }^{13} \mathrm{C} \mathrm{NMR}\left(101 \mathrm{MHz}, \mathrm{CDCl}_{3}\right)$ : $\delta \square(\mathrm{ppm})=148.8,147.0,134.0,119.5,111.4,111.3,55.9,55.8,28.5$, 15.8 .

\section{1-Ethylferrocene (9)}

The representative procedure $A$ was followed using Ferrocenecarboxaldehyde (107 mg, $0.5 \mathrm{mmol}$ ), Wilkinson's catalyst (30 $\mathrm{mg}, 6.5 \mathrm{~mol} \%)$ and a $0.50 \mathrm{M}$ soln of 2 in THF $(1.2 \mathrm{~mL}, 0,6 \mathrm{mmol})$. Column chromatography on silica gel (pentane/diethyl ether $100 / 0$ to 90/10) yielded 9 (86 mg, 80\%). ${ }^{1} \mathrm{H}$ NMR $\left(400 \mathrm{MHz}, \mathrm{CDCl}_{3}\right): \delta \square(\mathrm{ppm}) \square=$ 4.14-4.03 (m, $10 \mathrm{H}), 2.34$ (t, $J=7.5 \mathrm{~Hz}, 2 \mathrm{H}), 1.18$ (t, $J=7.5 \mathrm{~Hz}, 3 \mathrm{H}$ ). ${ }^{13} \mathrm{C}$ NMR $\left(101 \mathrm{MHz}, \mathrm{CDCl}_{3}\right): \delta \square(\mathrm{ppm})=91.4,68.6167 .6,67.2,22.4$, 14.7.

\section{2-Methoxy-2,6-dimethylnonane (10)}

The representative procedure $A$ was followed using 3,7-Dimethyl-7methoxyactanal (93 mg, $0.5 \mathrm{mmol})$, Wilkinson's catalyst $(30 \mathrm{mg}, 6.5$ mol\%) and a $0.50 \mathrm{M}$ soln of 2 in THF (1.2 mL, 0,6 mmol). Column chromatography on silica gel (pentane/diethyl ether $100 / 0$ to $90 / 10$ ) yielded 10 (65 mg, 69\%). ${ }^{1} \mathrm{H}$ NMR $\left(400 \mathrm{MHz}, \mathrm{CDCl}_{3}\right): \delta \square(\mathrm{ppm})=6.73(\mathrm{~d}$, $J=7.9 \mathrm{~Hz}, 1 \mathrm{H}), 6.66(\mathrm{~d}, J=1.6 \mathrm{~Hz}, 1 \mathrm{H}), 6.60(\mathrm{dd}, J=7.8,1.6 \mathrm{~Hz}, 1 \mathrm{H})$, $5.92(\mathrm{~s}, 2 \mathrm{H}$ ), 2.57 (dd, $J=13.5,6.2 \mathrm{~Hz}, 1 \mathrm{H}$ ), 2.30 (dd, $J=13.5,8.0 \mathrm{~Hz}$, $1 \mathrm{H}), 1.66-1.52(\mathrm{~m}, 1 \mathrm{H}), 1.48-1.33(\mathrm{~m}, 1 \mathrm{H}), 1.22-1.12(\mathrm{~m}, 1 \mathrm{H}), 0.92(\mathrm{t}, J$ $=7.4 \mathrm{~Hz}, 3 \mathrm{H}), 0.86(\mathrm{~d}, J=6.6 \mathrm{~Hz}, 3 \mathrm{H}) .{ }^{13} \mathrm{C}$ NMR $\left(101 \mathrm{MHz}, \mathrm{CDCl}_{3}\right)$ : $\delta \square(\mathrm{ppm})=147.5,145.5,135.7,122.0,109.6,108.0,100.8,43.2,34.0$, $29.2,19.0,11.6$

\section{5-(2-methylbutyl)-1,3-benzodioxole (11)}

The representative procedure A was followed using 2-Methyl-3-(3,4methylenedioxyphenyl)-propanal ( $96 \mathrm{mg}, 0.5 \mathrm{mmol})$, Wilkinson's catalyst (30 mg, $6.5 \mathrm{~mol} \%$ ) and a $0.50 \mathrm{M}$ soln of 2 in THF (1.2 mL, 0,6 mmol). Column chromatography on silica gel (pentane/diethyl ether $100 / 0$ to 90/10) yielded 11 (69 mg, 70\%). ${ }^{1} \mathrm{H}$ NMR $\left(400 \mathrm{MHz}, \mathrm{CDCl}_{3}\right): \delta \square(\mathrm{ppm}) \square=$ $6.73(\mathrm{~d}, J=7.9 \mathrm{~Hz}, 1 \mathrm{H}), 6.66(\mathrm{~d}, J=1.6 \mathrm{~Hz}, 1 \mathrm{H}), 6.60(\mathrm{dd}, J=7.8,1.6$ $\mathrm{Hz}, 1 \mathrm{H}), 5.92$ (s, $2 \mathrm{H}$ ), 2.57 (dd, $J=13.5,6.2 \mathrm{~Hz}, 1 \mathrm{H}), 2.30$ (dd, $J=13.5$, $8.0 \mathrm{~Hz}, 1 \mathrm{H}), 1.66-1.52(\mathrm{~m}, 1 \mathrm{H}), 1.48-1.33(\mathrm{~m}, 1 \mathrm{H}), 1.22-1.12(\mathrm{~m}, 1 \mathrm{H})$, $0.92(\mathrm{t}, J=7.4 \mathrm{~Hz}, 3 \mathrm{H}), 0.86(\mathrm{~d}, J=6.6 \mathrm{~Hz}, 3 \mathrm{H}) .{ }^{13} \mathrm{C} \mathrm{NMR}(101 \mathrm{MHz}$, $\left.\mathrm{CDCl}_{3}\right): \delta \square(\mathrm{ppm})=147.5,145.5,135.7,122.0,109.6,108.0,100.8,43.2$ $34.0,29.2,19.0,11.6$

\section{1-Ethyladamantane (12)}

The representative procedure $A$ was followed using 1 Adamantanecarboxaldhyde $(82 \mathrm{mg}, 0.5 \mathrm{mmol})$, Wilkinson's catalyst (30 $\mathrm{mg}, 6.5 \mathrm{~mol} \%$ ) and a $0.50 \mathrm{M}$ soln of 2 in THF $(1.2 \mathrm{~mL}, 0,6 \mathrm{mmol})$. Column chromatography on silica gel (pentane) yielded 12 (68 mg, 81\%). ${ }^{1} \mathrm{H}$ NMR $\left(400 \mathrm{MHz}^{\mathrm{CDCl}}{ }_{3}\right): \delta \square(\mathrm{ppm})=1.99-1.89(\mathrm{~m}, 3 \mathrm{H}), 1.75-1.59(\mathrm{~m}$ $6 \mathrm{H}), 1.45$ (d, $J=2.9 \mathrm{~Hz}, 6 \mathrm{H}), 1.10(\mathrm{q}, J=7.6 \mathrm{~Hz}, 2 \mathrm{H}), 0.79$ (t, $J=7.6$ 
$\mathrm{Hz}, 3 \mathrm{H}) .{ }^{13} \mathrm{C} \mathrm{NMR}\left(101 \mathrm{MHz}, \mathrm{CDCl}_{3}\right): \delta \square(\mathrm{ppm})=42.2,37.5,36.9,32.4$, 29.0, 7.0.

\section{4'-Ethylacetophenone (13)}

The representative procedure A was followed using 4Acetylbenzaldehyde $(74 \mathrm{mg}, 0.5 \mathrm{mmol})$, Wilkinson's catalyst $(30 \mathrm{mg}, 6.5$ mol\%) and a $0.50 \mathrm{M}$ soln of 2 in THF (1.2 mL, 0,6 mmol). Column chromatography on silica gel (pentane/diethyl ether 100/0 to 95/5) yielded $10(51 \mathrm{mg}, 65 \%)$. ${ }^{1} \mathrm{H}$ NMR $\left(400 \mathrm{MHz}, \mathrm{CDCl}_{3}\right): \delta \sqsupset(\mathrm{ppm})=7.89(\mathrm{~d}$, $J=8.3 \mathrm{~Hz}, 2 \mathrm{H}$ ), 7.28 (d, $J=8.1 \mathrm{~Hz}, 2 \mathrm{H}), 2.71(\mathrm{q}, J=7.6 \mathrm{~Hz}, 2 \mathrm{H}), 2.58$ $(\mathrm{s}, 3 \mathrm{H}), 1.26$ (t, $J=7.6 \mathrm{~Hz}, 3 \mathrm{H}) .{ }^{13} \mathrm{C}$ NMR $\left(101 \mathrm{MHz}, \mathrm{CDCl}_{3}\right): \delta \square(\mathrm{ppm})$ $\square=198.0,150.2,135.1,128.79,128.2,29.1,26.7,15.3$.

\section{1-Phenyl-1-hexanone (14)}

The representative procedure A was followed using 4-Benzoylpentanal ( $88 \mathrm{mg}, 0.5 \mathrm{mmol}$ ), Wilkinson's catalyst ( $30 \mathrm{mg}, 6.5 \mathrm{~mol} \%$ ) and a $0.50 \mathrm{M}$ soln of 2 in THF (1.2 mL, 0,6 mmol). Column chromatography on silica gel (pentane/diethyl ether $100 / 0$ to $95 / 5)$ yielded $14(50 \mathrm{mg}, 55 \%) .{ }^{1} \mathrm{H}$ $\operatorname{NMR}\left(400 \mathrm{MHz}, \mathrm{CDCl}_{3}\right): \delta \square(\mathrm{ppm}) \square=7.90-7.85$ (m, $\left.2 \mathrm{H}\right), 7.49-7.44$ (m, 1 H), 7.44-7.33 (m, $2 \mathrm{H}), 2.86(\mathrm{t}, J=8.0 \mathrm{~Hz}, 2 \mathrm{H}), 1.70-1.60(\mathrm{~m}, 2 \mathrm{H}), 1.32$ $1.25(\mathrm{~m}, 4 \mathrm{H}), 0,83(\mathrm{t}, J=8.0 \mathrm{~Hz}, 3 \mathrm{H}) .{ }^{13} \mathrm{C}$ NMR $\left(101 \mathrm{MHz}, \mathrm{CDCl}_{3}\right)$ : $\delta \square(\mathrm{ppm})=200.6,137.2,132.9,128.6,128.1,38.6,31.6,24.1,22.6,14.0$.

\section{1-Phenyl-1-heptanone (15)}

The representative procedure A was followed using 6-Oxo-6phenylhexanal $(95 \mathrm{mg}, 0.5 \mathrm{mmol})$, Wilkinson's catalyst $(30 \mathrm{mg}, 6.5$ mol\%) and a $0.50 \mathrm{M}$ soln of 2 in THF (1.2 mL, 0,6 mmol). Column chromatography on silica gel (pentane/diethyl ether $100 / 0$ to $95 / 5$ ) yielded $15(63 \mathrm{mg}, 65 \%) .{ }^{1} \mathrm{H}$ NMR $\left(400 \mathrm{MHz}, \mathrm{CDCl}_{3}\right): \delta \square(\mathrm{ppm}) \square=7.94$ (d, $J=8.0 \mathrm{~Hz}, 2 \mathrm{H}), 7.59-7.50(\mathrm{~m}, 1 \mathrm{H}), 7.50-7.39(\mathrm{~m}, 2 \mathrm{H}), 2.93(\mathrm{t}, J=$ $8.0 \mathrm{~Hz}, 2 \mathrm{H}), 1.78-1.66(\mathrm{~m}, 2 \mathrm{H}), 1.42-1.25(\mathrm{~m}, 6 \mathrm{H}), 0,88(\mathrm{t}, J=8.0 \mathrm{~Hz}, 3$ H). ${ }^{13} \mathrm{C}$ NMR $\left(101 \mathrm{MHz}, \mathrm{CDCl}_{3}\right): \delta \square(\mathrm{ppm})=200.5,137.2,132.9,128.6$, $128.1,38.7,31.7,29.1,24.4,22.6,14.1$

\section{(2R)-1-Triphenylmethoxy-2-methylbutane (16)}

The representative procedure A was followed using (2S)-2-Methyl-3triphenylmethoxypropanal $(165 \mathrm{mg}, 0.5 \mathrm{mmol})$, Wilkinson's catalyst (30 $\mathrm{mg}, 6.5 \mathrm{~mol} \%)$ and a $0.50 \mathrm{M}$ soln of 2 in THF (1.2 mL, 0,6 mmol). Column chromatography on silica gel (pentane/diethyl ether 100/0 to 90/10) yielded $16(130 \mathrm{mg}, 78 \%) .{ }^{1} \mathrm{H} \mathrm{NMR}\left(400 \mathrm{MHz}, \mathrm{CDCl}_{3}\right): \delta \square(\mathrm{ppm})=$ 7.51-7.46 (m, $6 \mathrm{H}), 7.31$ (t, $J=7.4 \mathrm{~Hz}, 5 \mathrm{H})$, 7.29-7.20 (m, 3 H), 2.99 (dd, $J=8.7,6.0 \mathrm{~Hz}, 1 \mathrm{H}), 2.91(\mathrm{dd}, J=8.7,6.3 \mathrm{~Hz}, 1 \mathrm{H}), 1.74-1.64(\mathrm{~m}, 1 \mathrm{H})$, 1.57-1.47 (m, $1 \mathrm{H}), 1.24-1.15(\mathrm{~m}, 1 \mathrm{H}), 0.97(\mathrm{~d}, J=6.7 \mathrm{~Hz}, 3 \mathrm{H}), 0.84$ (t, $J$ $=7.5 \mathrm{~Hz}, 3 \mathrm{H}) .{ }^{13} \mathrm{C}$ NMR $\left(101 \mathrm{MHz}, \mathrm{CDCl}_{3}\right): \delta \square(\mathrm{ppm}) \square=144.8,128.9$, $127.8,126.9,86.2,68.3,35.7,26.6,17.1,11.5$. HRMS (ESI) $\mathrm{m} / \mathrm{z}$ calculated for $\left[\mathrm{C}_{24} \mathrm{H}_{26} \mathrm{NaO}\right]^{+}$353.1876; found 353.1883 .

Representative Procedure B for the Domino MethylenationHydrogenation of ketones: To a solution of ketone $(0.5 \mathrm{mmol})$ and Wilkinson catalyst $(7 \mathrm{~mol} \%)$ in dry $\mathrm{CH}_{2} \mathrm{Cl}_{2}(0.5 \mathrm{~mL})$ under $\mathrm{H}_{2}(1 \mathrm{~atm})$, were successively added at $25^{\circ} \mathrm{C}$ a $1 \mathrm{M}$ soln of $\mathrm{TiCl}_{4}$ in $\mathrm{CH}_{2} \mathrm{Cl}_{2}(0.6$ $\mathrm{mmoL})$ and a $0.5 \mathrm{M}$ soln of 2 in THF $(0,55 \mathrm{mmol})$. After $20 \mathrm{~h}$ under vigorous stirring, the mixture was purified by flash column chromatography (silica gel, pentane/diethyl ether as eluent 100/0 to $50 / 50$ ) to give desired compound. All compounds were obtained as oils.

\section{a-Methyltetralin (20)}

The representative procedure B was followed using $\alpha$-Tetralone $(73 \mathrm{mg}$, $0.5 \mathrm{mmol}$ ), Wilkinson's catalyst ( $33 \mathrm{mg}, 7 \mathrm{~mol} \%$ ), a $1 \mathrm{M}$ soln of $\mathrm{TiCl}_{4}$ in $\mathrm{CH}_{2} \mathrm{Cl}_{2}(0.6 \mathrm{~mL}, 0,6 \mathrm{mmoL})$ and a $0.50 \mathrm{M}$ soln of 2 in THF (1.05 mL, 0.55 $\mathrm{mmol}$ ). Column chromatography on silica gel (pentane) yielded 21 (65 $\mathrm{mg}, 86 \%) .{ }^{1} \mathrm{H}$ NMR $\left(400 \mathrm{MHz}, \mathrm{CDCl}_{3}\right): \delta \square(\mathrm{ppm})=7.21(\mathrm{~d}, J=7.3 \mathrm{~Hz}, 1$ $H)$, 7.17-7.03 (m, $3 \mathrm{H}), 2.92(\mathrm{~m}, 1 \mathrm{H}), 2.77(\mathrm{~m}, 2 \mathrm{H}), 1.99-1.83(\mathrm{~m}, 2 \mathrm{H})$, $1.74(\mathrm{~m}, 1 \mathrm{H}), 1.59-1.52(\mathrm{~m}, 1 \mathrm{H}), 1.31(\mathrm{~d}, J=7.0 \mathrm{~Hz}, 3 \mathrm{H}) .{ }^{13} \mathrm{C}$ NMR $(75$ $\left.\mathrm{MHz}, \mathrm{CDCl}_{3}\right): \delta \square(\mathrm{ppm})=142.3,137.0,129.1,128.2,125.7,125.5,32.6$, $31.6,30.1,23.0,20.6$

\section{8-Methyl-1,4-dioxaspiro[4.5]decane (21)}

The representative procedure $B$ was followed using 1,4dioxaspiro[4.5]decan-8-one (78 mg, $0.5 \mathrm{mmol})$, Wilkinson's catalyst (33 $\mathrm{mg}, 7 \mathrm{~mol} \%)$, a $1 \mathrm{M}$ soln of $\mathrm{TiCl}_{4}$ in $\mathrm{CH}_{2} \mathrm{Cl}_{2}(0.6 \mathrm{~mL}, 0,6 \mathrm{mmoL})$ and a $0.50 \mathrm{M}$ soln of 2 in THF $(1.05 \mathrm{~mL}, 0.55 \mathrm{mmol})$. Column chromatography on silica gel (pentane/diethyl ether 100/0 to 70/30) yielded $22(56 \mathrm{mg}$, $70 \%) .{ }^{1} \mathrm{H}$ NMR $\left(400 \mathrm{MHz}, \mathrm{CDCl}_{3}\right): \delta \square(\mathrm{ppm})=3.90(\mathrm{~s}, 4 \mathrm{H}), 1.74-1.57(\mathrm{~m}$, $4 \mathrm{H}$ ), $1.55-1.44(\mathrm{~m}, 2 \mathrm{H}), 1.39$ (tdd, $J=9.9,7.1,5.0 \mathrm{~Hz}, 1 \mathrm{H}$ ), 1.20 (tdd, $J$ $=13.9,11.2,3.5 \mathrm{~Hz}, 2 \mathrm{H}), 0.88(\mathrm{~d}, J=6.5 \mathrm{~Hz}, 3 \mathrm{H}) .{ }^{13} \mathrm{C}$ NMR $(101 \mathrm{MHz}$, $\left.\mathrm{CDCl}_{3}\right): \delta \sqcup(\mathrm{ppm})=109.1,64.3,64.2,34.7,32.4,31.5,21.7$.

\section{2-Methylpropoxy-benzene (22)}

The representative procedure $\mathrm{B}$ was followed using 1-Phenoxyacetone (75 mg, $0.5 \mathrm{mmol}$ ), Wilkinson's catalyst ( $33 \mathrm{mg}, 7 \mathrm{~mol} \%$ ), a $1 \mathrm{M}$ soln of $\mathrm{TiCl}_{4}$ in $\mathrm{CH}_{2} \mathrm{Cl}_{2}(0.6 \mathrm{~mL}, 0,6 \mathrm{mmoL})$ and a $0.50 \mathrm{M}$ soln of 2 in THF (1.05 $\mathrm{mL}, 0.55 \mathrm{mmol})$. Column chromatography on silica gel (pentane/diethyl ether $100 / 0$ to $95 / 5)$ yielded 23 (63 mg, 82\%). ${ }^{1} \mathrm{H}$ NMR $(400 \mathrm{MHz}$, $\left.\mathrm{CDCl}_{3}\right): \delta \square(\mathrm{ppm})=7.35-7.26(\mathrm{~m}, 2 \mathrm{H}), 6.99-6.84(\mathrm{~m}, 3 \mathrm{H}), 3.73(\mathrm{~d}, J=$ $6.5 \mathrm{~Hz}, 2 \mathrm{H}$ ), 2.10 (heptuplet, $J=6.6 \mathrm{~Hz}, 1 \mathrm{H}), 1.04(\mathrm{~d}, J=6.7 \mathrm{~Hz}, 6 \mathrm{H}$ ). ${ }^{13} \mathrm{C}$ NMR $\left(101 \mathrm{MHz}, \mathrm{CDCl}_{3}\right): \delta \square(\mathrm{ppm})=159.4,129.5,120.5,114.7,74.4$, 28.4, 19.4 .

\section{Benzyl isobutyrate (23)}

The representative procedure $\mathrm{B}$ was followed using Benzyl pyruvate (75 $\mathrm{mg}, 0.5 \mathrm{mmol}$ ), Wilkinson's catalyst ( $33 \mathrm{mg}, 7 \mathrm{~mol} \%$ ), a $1 \mathrm{M}$ soln of $\mathrm{TiCl}_{4}$ in $\mathrm{CH}_{2} \mathrm{Cl}_{2}(0.6 \mathrm{~mL}, 0,6 \mathrm{mmoL})$ and a $0.50 \mathrm{M}$ soln of 2 in THF $(1.05 \mathrm{~mL}$, $0.55 \mathrm{mmol}$ ). Column chromatography on silica gel (pentane/diethyl ether 100/0 to 80/20) yielded 24 (63 mg, 82\%). 1H NMR (400 MHz, CDCl3) : $\delta \sqcup(\mathrm{ppm})=7.39-7.31(\mathrm{~m}, 5 \mathrm{H}), 5.12(\mathrm{~s}, 2 \mathrm{H}), 2.61$ (hept, $J=7.0 \mathrm{~Hz}, 1 \mathrm{H}$ ), 1.19 (d, $J=7.0 \mathrm{~Hz}, 6 \mathrm{H}) .13 \mathrm{C} \mathrm{NMR}(101 \mathrm{MHz}, \mathrm{CDCl} 3): \delta \square(\mathrm{ppm})=176.9$, $136.4,128.6,128.1,128.0,66.1,34.1,19.1$.

\section{$\beta \square$ Methyltetralin (24) and 2-Methyl-3,4-dihydronaphthalene (25)}

The representative procedure $B$ was followed using $\beta$-Tetralone $(73 \mathrm{mg}$, $0.5 \mathrm{mmol}$ ), Wilkinson's catalyst ( $33 \mathrm{mg}, 7 \mathrm{~mol} \%$ ), a $1 \mathrm{M}$ soln of $\mathrm{TiCl}_{4}$ in $\mathrm{CH}_{2} \mathrm{Cl}_{2}(0.6 \mathrm{~mL}, 0,6 \mathrm{mmoL})$ and a $0.50 \mathrm{M}$ soln of 2 in THF (1.05 mL, 0.55 $\mathrm{mmol}$ ). Column chromatography on silica gel (pentane) yielded a 73/27 mixture of 25 and $26(58.5 \mathrm{mg}, 78 \%)$. ${ }^{1} \mathrm{H}$ NMR $\left(400 \mathrm{MHz}, \mathrm{CDCl}_{3}\right): \delta=$ 7.15-7.04 (m, 3.72 H, $25+26), 6.99-6.95(\mathrm{~m}, 0.27 \mathrm{H}, 26), 6.23(\mathrm{~d}, J=1.5$ $\mathrm{Hz}, 0.27 \mathrm{H}, 26), 2.90-2.78$ (m, 2.72 H, 25), 2.42 (ddd, $J=16.5,10.6,1.3$ $\mathrm{Hz}, 0.71 \mathrm{H}, 26), 2.29-2.22(\mathrm{~m}, 0.58 \mathrm{H}, 26), 1.95-1.80(\mathrm{~m}, 2.35 \mathrm{H}, 25+\mathrm{Me}$ 26), $1.46-1.37(\mathrm{~m}, 0.72 \mathrm{H}, 25), 1.08(\mathrm{~d}, J=6.5 \mathrm{~Hz}, 2.19 \mathrm{H}, \mathrm{Me} 25) .{ }^{13} \mathrm{C}$ NMR $\left(75 \mathrm{MHz}, \mathrm{CDCl}_{3}\right): \delta=138.3,137.1,136.8,135.2,134.2,129.2$, 129.0, 127.3, 126.5, 126.1, 125.9, 125.6, 125.5, 125.2, 122.9, 38.3, 31.7, $29.4,29.0,28.2,23.6,22.1$

\section{2-Phenyl-hexane (26) and 2-Phenyl-1-hexene (27)}

The representative procedure $\mathrm{B}$ was followed using Valerophenone ( 81 $\mathrm{mg}, 0.5 \mathrm{mmol}$ ), Wilkinson's catalyst ( $33 \mathrm{mg}, 7 \mathrm{~mol} \%$ ), a $1 \mathrm{M}$ soln of $\mathrm{TiCl}_{4}$ in $\mathrm{CH}_{2} \mathrm{Cl}_{2}(0.6 \mathrm{~mL}, 0,6 \mathrm{mmoL})$ and a $0.50 \mathrm{M}$ soln of 2 in THF $(1.05 \mathrm{~mL}$, $0.55 \mathrm{mmol}$ ). Column chromatography on silica gel (pentane) yielded a $80 / 20$ mixture of 27 and 28 (71 mg, 85\%). ${ }^{1} \mathrm{H} \mathrm{NMR}\left(400 \mathrm{MHz}, \mathrm{CDCl}_{3}\right)$ : $\delta=7.45-7.17(\mathrm{~m}, 5.38 \mathrm{H}, 27+28), 5.28(\mathrm{~s}, 0.19 \mathrm{H}, 28), 5.07(\mathrm{~s}, 0.19 \mathrm{H}$ 28), 2.69 (h, $J=7.1 \mathrm{~Hz}, 0.79 \mathrm{H}, 27$ ), 2.53 (t, $J=7.5 \mathrm{~Hz}, 0.39 \mathrm{H}, 28$ ), $1.67-1.09(\mathrm{~m}, 8.63 \mathrm{H}, 27+28), 0.95-0.83\left(\mathrm{~m}, 3 \mathrm{H}, \mathrm{CH}_{3} n \mathrm{nBu} 27+28\right) .{ }^{13} \mathrm{C}$ NMR $\left(75 \mathrm{MHz}, \mathrm{CDCl}_{3}\right): \delta=148.9,148.1,141.7,128.4,128.4,127.4$, $127.1,126.3,125.9,112.1,40.1,38.3,35.2,30.6,30.1,22.9,22.6,22.5$ 14.2, 14.1 . 


\section{Acknowledgements}

The authors wish to thank Omar Khaled from IPCM for HRMS analysis and University of Carthage for financial support.

Keywords: Methylenation-Hydrogenation cascade $\bullet$ Domino process $\bullet$ Chemoselectivity $•$ Matsubara's reagent $•$ Wilkinson's catalyst
J. Am. Chem. Soc., 2010, 132, 17452; d) M. Sada, M. Uchiyama, S. Matsubara, Synlett 2014, 25, 2831.

[14] H. Lebel, M. Davi, G. T. Stoklosa, J. Org. Chem., 2008, 73, 6828.

[15] a) D. A. Evans, H. A. Rajapakse, A. Chiu, D. Stenkamp, Angew. Chem Int. Ed. 2002, 41, 4573; b) K. P. Shelly, L. Weiler, Can. J. Chem 1988 66, 1359; (c) L. Lombardo, Tetrahedron Lett. 1982, 23, 4293.

[16] See supporting information.

[17] The optimal reported protocol to convert ketones into alkenes involves a $2 / \mathrm{TiCl}_{4}=2: 1$ ratio in order to convert $\mathrm{TiCl}_{4}$ into $\mathrm{TiCl}_{2}$ or $\mathrm{TiCl}_{3}$. $\mathrm{A} 2 / \mathrm{TiCl}_{4}$ $=1: 1$ ratio only affords $26 \%$ of the alkene. ${ }^{[13 a-c]}$ Conversely, in our conditions, a $2 / \mathrm{TiCl}_{4}=1: 1.1$ ratio is optimal: the combination of $\mathrm{TiCl}_{4}$ and Wilkinson's catalyst under $\mathrm{H}_{2}$ atmosphere could perhaps lead to in situ formation of $\mathrm{TiCl}_{2}$ or $\mathrm{TiCl}_{3}$ more suitable for the methylenation reaction.

\section{References}

[1] a) R. A. Sheldon, Green Chem., 2007, 9, 1273; b) D. J. C. Constable, P. J. Dunn, J. D. Hayler, G. R. Humphrey, J. L. Jr. Leazer, R. J. Linderman, K. Lorenz, J. Manley, B. A. Pearlman, A. Wells, A. Zaks, T. Y. Zhang, Green Chem. 2007, 9, 411.

[2] a) P. T. Anastas, M. M. Kirchhoff, Acc. Chem. Res. 2002, 35, 686; b) P. T. Anastas, J. C. Warner, in Green chemistry theory and practice, (Oxford, Oxford University press, 1998, pp135).

[3] For a seminal review on domino reactions, see: a) L. F. Tietze, Chem. Rev., 1996, 96, 115; b) L. F. Tietze, G. Brasche, K. M. Gericke, in Domino Reactions in Organic Synthesis (Wiley-VCH,Weinheim, 2006), c) S. Borukhova, L. F. Tietze, Green Processing and Synthesis 2014, 3, 501 .

[4] a) T. Kawasaki, A. Ogawa, R. Terashima, T. Saheki, N. Ban, H. Sekiguchi, K. Sakaguchi, M. Sakamoto, J. Org. Chem. 2005, 70, 2957 b) T. Kawasaki, M. Shinada, D. Kamimura, M. Ohzono, A. Ogawa Chem. Commun. 2006, 4, 420; c) B. Breit, S. K. Zahn, Angew. Chem. Int Ed. 1999, 38, 969; d) B. Breit, S. K. Zahn, Tetrahedron 2005, 61 6171; e) A. Farwick, G. Helmchen, Adv. Synth. Catal. 2010, 352, 1023; f) G. Prasad Mishra, G. Venkata Ramana, B. Venkateswara Rao, Chem. Commun. 2008, 3423.

[5] H. Mizoguchi, H. Oikawa, H. Oguri, Nature Chem. 2014, 6, 57.

[6] J. B. Rhoden, M. Bouvet, S. Izenwasser, D. Wade, S. A. Lomenzo, M. L. Trudell, Biorg. Med. Chem. 2005, 13, 5623.

[7] T. Yamane, M. Izhizaki, M. Suzuki, M. Takahashi, K. Hiroya, S. Takano, K. Ogasawara, Heterocycles 1996, 42, 65.

[8] H. Lebel, C. Ladjel, J. Org. Chem. 2005, 70, 10159.

[9] S. Matsubara, K. Oshima, in Modern Carbonyl Olefination: Methods and Applications (Takeda, T., Ed.; Wiley-VCH: Weinheim, 2004, Chap. $5,200)$.

[10] a) J. F. Young, J. A. Osborn, F. H. Jardine, G. Wilkinson, Chem. Commun. 1965, 131; b) J. A. Osborn, F. H. Jardine, J. F. Young, G. Wilkinson, J. Chem. Soc. A, 1966, 1711; c) J. A. Osborn, G. Wilkinson, Inorganic Syntheses 1967, 10, 67.

[11] a) L. N. Nysted, US Patent 3865 848, 1975 ; Chem. Abstr. 1975, 83, 10406q; b) L. N. Nysted, US Patent 3960 904, 1976 ; Chem. Abstr 1976, 85, 94618n; c) S. Matsubara, M. Sugihara, K. Utimoto, Synlet 1998, 313.

[12] K. Takai, T. Kakiuchi, Y. Kataota, K. Utimoto, J. Org. Chem. 1994, 59, 2668;

[13] a) S. Matsubara, T. Mizuno, T. Otake, M. Kobata, K. Utimoto, K. Takai, Synlett 1998, 1369; b) S. Matsubara, H. Yoshino, Y. Yamamoto, K. Oshima, H. Matsuoka, K. Matsumoto, K. Ishikawa, E Matsubara, J. Organometallic Chem. 2005, 690, 5546; c) M. Sada, S. Komagawa, M. Uchiyama, M. Kobata, T. Mizuno, K. Utimoto, K. Oshima, S. Matsubara 
